\author{
Michał A. Michalski \\ Adam Mickiewicz University in Poznan \\ e-mail: mmichal@amu.edu.pl \\ Jakub Isański \\ Adam Mickiewicz University in Poznan \\ e-mail: isan@amu.edu.pl
}

\title{
Społeczno-kulturowe aspekty zmian dzietności i ich konsekwencje dla rozwoju społeczno-gospodarczego
}

\section{Economic Development and Social Development. Socio-cultural Aspects of Fertility Changes and their Consequences}

Thesis: Present-day radical fertility changes are determined by socio-cultural factors and will have consequences for the economy and its development potential.

Current changes in the fertility rate in Poland are the subject of many discussions and arguments. It means that, among the challenges for researchers, firstly, they have to understand the background to this issue and identify the factors influencing procreative decisions. Secondly, they should demonstrate how population growth changes and will change society, and the economy in particular. Our paper analyzes the mentioned research problem by engaging tools from sociology and cultural studies to examine the influence of norms, values, beliefs, attitudes and behaviours on the changing level of birth rate and its economic consequences for the current and future functioning of the social order. The purpose of the analyses is to deepen and compare the results of findings from such disciplines as demography, statistics and economics, and present them against a background of socio-cultural transformations, which seem to be very important in the context of Polish females and males making procreative decisions. Additionally, the paper presents links between fertility and economic development, which often seem to be ignored or underestimated.

Keywords: fertility rate, socio-cultural context of economic changes, family, economy, development

JEL Classification: J11, J13, Z13 


\section{Wprowadzenie}

Reprodukcja społeczna jest warunkiem istnienia życia społecznego w wymiarze międzypokoleniowym. Składają się na nią zarówno prokreacja, jak i wychowanie członków kolejnego pokolenia przy udziale wcześniejszych generacji. Przedmiotem naszego zainteresowania będzie także społeczny kontekst tych zachowań. Uważamy, że aktualne, bardzo niskie wskaźniki dzietności charakteryzujące kraje europejskie, a szczególnie Polskę, są skutkiem wielu procesów społeczno-kulturowych, które przedstawimy poniżej. Już na wstępie także zaznaczamy, że aktualny poziom dzietności stanie się w przyszłości przyczyną szeregu przemian społecznych, kulturowych, ekonomicznych. W tym więc znaczeniu celem naszego artykułu jest dokonanie diagnozy istniejącego stanu - przemian dzietności - oraz przedstawienie na tej podstawie prognoz dotyczących przyszłości.

Nasze rozważania sytuujemy w kontekście rozwoju, który niewątpliwie stanowi ważny punkt odniesienia i ewaluacji procesów zachodzących w obrębie społeczeństwa. Napotykamy tu jednak problem natury definicyjnej, który sprowadzić można do pytania o to, jak rozwój rozumieć i jak go mierzyć. Ważną inspiracją dla naszych rozważań jest propozycja Michała Gabriela Woźniaka, który rozwija koncepcję rozwoju zintegrowanego, starającą się uchwycić złożoność i współzależność różnych wymiarów życia ludzkiego i społecznego ${ }^{1}$. Reasumując, przyjmujemy takie rozumienie tych dwóch kategorii, według którego pomiędzy rozwojem społecznym i gospodarczym zachodzi stosunek komplementarności oraz synergii. Mówiąc inaczej, dobrostan - jako efekt pierwszego - oraz dobrobyt - jako wynik drugiego, winny się w długiej perspektywie wspierać i przyczyniać do spójności, trwałości i funkcjonalności społeczeństwa, w którym kluczową rolę odgrywa zasada dobra wspólnego. W jakimś sensie taka koncepcja rozwoju koresponduje z postulatem społecznej gospodarki rynkowej, który zapisany jest w artykule dwudziestym Konstytucji Rzeczypospolitej Polskiej.

W kontekście interesującego nas rozwoju uważamy za ważne, aby zwrócić uwagę na zmiany dzietności i ich przyczyny. Okazuje się, że w ich wyniku ład społeczno-gospodarczy, jaki znamy, odchodzi do przeszłości, a na naszych oczach wyłania się nowy, który ujawnia zjawiska i procesy niosące z sobą nieznane wcześniej wyzwania i paradoksy. Dla nauk społecznych oznacza to między innymi rozstanie się $\mathrm{z}$ - często być może nieuświadamianym - przekonaniem, że dzietność należy traktować jako zmienną niezależną. Innymi słowy, żyjemy w epoce, w której szczególnie należy zdać sobie sprawę z tego, że nie tylko społeczeństwo podlega głębokim i złożonym przemianom, ale że to, co obserwujemy, może oznaczać, iż zaczyna ono przeobrażać się w sposób nieodwracalny. Choć taki scenariusz wydaje się dziś nieprawdopodobny, to zapewne analizowane tu zmiany będą prowadziły do rozmaitych napięć i konfliktów, np. w wymiarze relacji międzypokoleniowych ${ }^{2}$, jakie już obserwujemy. Coraz wyraźniejsze stają się przeobrażenia struktury społecznej, które mają i będą miały poważne konsekwencje

\footnotetext{
${ }^{1}$ M.G. Woźniak, Współczesne niedostosowania instytucjonalne z perspektywy wyzwań rozwojowych Polski, „Nierówności Społeczne a Wzrost Gospodarczy”2017, nr 50 (2), s. 22, DOI:10.15584/nsawg.2017.2.1.

2 J. Martin, E. Whitehouse, The conflict between generations: Fact or fiction?, OECD Observer, oecdobserver.org: _Fact_or_fiction_.html (data dostępu: styczeń 2018).
} 
nie tylko społeczne, ale i gospodarcze. Oznacza to, że warunki funkcjonowania tego, co określa się w literaturze przedmiotu mianem umowy międzypokoleniowej, ulegają zasadniczym przemianom ${ }^{3}$.

Aktualny wskaźnik dzietności w Polsce jest bardzo niski - jego wartość w roku 2016 wyniosła $1,36^{4}$, a nasz kraj znajduje się w związku z tym na jednym z ostatnich miejsc w Europie i na świecie. Warto dodać, że kraje europejskie - mimo wielu programów rządowych mających stymulować dzietnośćc ${ }^{5}$ zajmują także ostatnie miejsca na tej liście. Taki poziom dzietności nie gwarantuje zastępowalności pokoleń, co będzie miało, jak już wspomniano, daleko idące konsekwencje dla życia gospodarczego i społecznego w najbliższej przyszłości. Co ciekawe, jeszcze na przełomie lat 80. i 90. XX wieku dzietność w Polsce pozostawała na względnie wysokim poziomie, a liczba ludności rosła. Transformacja ustrojowa początku lat 90. przyczyniła się jednak do głębokiej przemiany warunków życia społecznego, które wpłynęły na przemiany stylu życia rodzinnego. Zmniejszyła się wielkość przeciętnej rodziny, rzadsze stały się rodziny wielopokoleniowe, a Polacy coraz później zaczęli zawierać związki małżeńskie. Równocześnie zmniejszyła się też trwałość rodziny ${ }^{6}$ oraz wzrósł odsetek urodzeń pozamałżeńskich (z 5\% w 1989 r. do 23\% w 2012 r. ${ }^{7}$ ), oznaczający teraz nie tylko samotne rodzicielstwo, ale i posiadanie dziecka przez pary będące w związkach niesformalizowanych. Należy także wspomnieć o coraz późniejszym wieku rodzenia pierwszego dziecka przez kobiety oraz o tym, że zwiększyła się liczba rodzin i par żyjących bez dzieci i nieplanujących rodzicielstwa. Nie można także zapominać, że przemiany dotyczące życia społecznego zachodzą w kontekście nie mniej radykalnych przemian warunków życia gospodarczego ${ }^{8}$. Jeśli spojrzeć wyłącznie

\footnotetext{
${ }^{3}$ Cf. np. P. Szukalski, Czym jest solidarność międzypokoleniowa? [w:] Jakość życia seniorów w XXI wieku z perspektywy polityki społecznej, red. D. Kałuża, P. Szukalski, Wydawnictwo Biblioteka, Łódź 2010 , s. 87.

${ }^{4}$ Za raportem Głównego Urzędu Statystycznego, J. Stańczak, K. Stelmach, M. Urbanowicz, Małżeństwa oraz dzietność w Polsce, GUS 2016; oraz danymi Eurostat. Cf. Fertility statistics, Eurostat, http://ec.europa.eu/eurostat/statistics-explained/index.php/Fertility_statistics (data dostępu: styczeń 2018).

${ }^{5}$ Warto także dodać, że oferowane w różnych krajach kwoty znacznie różnią się od siebie. Według raportu opracowanego przez firmę PWC, wysokość średniego rocznego wsparcia dla rodziny $2+2$ w Polsce w 2015 roku, przed wprowadzeniem programu Rodzina 500+, wynosiła 530 euro, wobec średniej unijnej 2347 euro i wsparcia w wysokości 6772 euro udzielanego rodzinie 2+2 we Francji i 9264 euro w Luksemburgu, przy czym kwoty te stanowiły 2,4\% przeciętnego rocznego wynagrodzenia małżeństwa/pary w Polsce, 13,7\% we Francji i 8,2\% w Luksemburgu, (Cf. Ulgi podatkowe i świadczenia rodzinne w UE, Raport PriceWaterHouseCoopers, listopad 2015). Program Rodzina 500+ cieszył się w Polsce na początku 2017 roku, po roku od jego wprowadzenia, aprobatą 77\% Polaków, a polityka państwa wobec rodziny oceniana jest „,dostatecznie ”, „dobrze” lub „,bardzo dobrze” przez 86\% ankietowanych, za: B. Roguska, Ocena programu „Rodzina 500+” po blisko roku od jego wprowadzenia, Komunikat z badań Centrum Badania Opinii Społecznej nr 36/2017, http://www.cbos.pl/PL/publikacje/raporty.php (data dostępu: maj 2017).

${ }^{6}$ Cf. Z. Tyszka, A. Wachowiak, Podstawowe pojęcia i zagadnienia socjologii rodziny, Wydawnictwo Akademii Rolniczej im. A.Cieszkowskiego, Poznań 1997.

${ }^{7}$ Niska dzietność w Polsce w kontekście percepcji Polaków. Diagnoza społeczna 2013, red. I.E. Kotowska, Warszawa 2014.

${ }^{8}$ Jako przykłady można podać chociażby takie prace, jak G.W. Kołodko, Droga do teraz, Prószyński i S-ka, Warszawa 2014 czy K. Poznański, Obłęd reform. Wyprzedaż Polski, Ludowa Spółdzielnia Wydawnicza, Warszawa 2001.
} 
na syntetyczne miary typu PKB, to należy stwierdzić, że mierzone za jego pomocą bogactwo wzrosło w ciągu blisko trzech dekad zmian. Wartość Produktu Krajowego Brutto Polski w stosunku do roku 1989 podwoiła swoją wartość już w 2013 roku9.

Wymienione powyżej zjawiska i przemiany istotnie wpłynęły na życie rodzinne, a zwłaszcza na analizowane przez nas zjawisko dzietności. Poza zmianą wartości wskaźnika określającego liczbę dzieci przypadających na jedną kobietę nie mniej istotna zmiana dokonała się w sferze postrzegania i traktowania dzieci. Ujawniły się potrzeby, a wraz z nimi możliwości ich zaspokojenia, zapewnienia dzieciom dodatkowych umiejętności, tak cennych na zmieniającym się rynku pracy. Rozpoczęło się masowe inwestowanie w siebie, w swój rozwój, w karierę i pozycję społeczną ${ }^{10}$. W tych nowych realiach coraz wyraźniej zaczął ujawniać się swoisty konflikt między życiem rodzinnym a aspiracjami dotyczącymi z jednej strony realizacji indywidualnych pragnień poprzez konsumpcję, z drugiej związanymi z inwestowaniem w swój kapitał ludzki. Problem ten wcześniej w społeczeństwach Zachodu dostrzegł Stefano Zamagni, który stwierdza, że:

\section{(...) rodzina jest dzisiaj najważniejszym przejawem wolnego czasu jako trwania (w sen- sie nadanym przez Henri'ego Bergsona), które nie jest zagarnięte ani przez pracę, ani przez konsumpcje, to znaczy czasu wolnego jako czasu przeznaczonego na działania o charakterze relacyjnym, już to wytwórcze, już to konsumpcyjne. (...) wspótcześnie zor- ganizowane społeczeństwo uparcie dąży do skrócenia czasu wolnego, ponieważ traktuje konsumpcjejako działalność gospodarcza par excellance, a zatem dąży do uszczuplenia obszaru właściwego rodzinie ${ }^{11}$.}

Można zauważyć, że konkurencję dla życia rodzinnego w odniesieniu do dzieci stanowią na przykład dodatkowe zajęcia pozalekcyjne, które z każdym rokiem stają się w Polsce coraz powszechniejsze. Z badań społecznych wynika, że w roku szkolnym 2016/2017 opłacała je większość rodziców, przy czym warto także zauważyć, iż odsetek ten wśród rodziców z wyższym wykształceniem wyniósł 93\%, wobec 59\% w przypadku rodziców posiadających wykształcenie średnie, 38\% rodziców z wykształceniem zawodowym oraz $21 \%$ rodzin, w których rodzice mają wykształcenie podstawowe ${ }^{12}$. Wśród zajęć tych najpopularniejsze są dodatkowe lekcje języków obcych, zajęcia sportowe, artystyczne, kursy komputerowe czy korepetycje z przedmiotów nauczanych w szkole.

\footnotetext{
${ }^{9}$ Polska 1989-2014, red. H. Dmochowska, Główny Urząd Statystyczny, stat.gov (data dostępu: maj 2017).

${ }^{10}$ Cf. M. Ziółkowski, Przemiany interesów i wartości społeczeństwa polskiego, Humaniora, Poznań 2000, s. 187.

${ }^{11}$ S. Zamagni, Rodzina jako podmiot gospodarczy, „Społeczeństwo” 2003, nr 2 (54), s. 236.

${ }^{12}$ Cf. B. Badora, Wydatki rodziców na edukację dzieci w roku szkolnym 2016/2017, Raport z badań Centrum Badania Opinii Społecznej, 2016, http://cbos.pl/SPISKOM.POL/2016/K_157_16.PDF (data dostępu: maj 2017). Wymieniane w raporcie wydatki uwzględniają już efekt wprowadzonego programu Rodzina 500+, wydaje się zatem, że nie różnice w zamożności, ale raczej świadomość inwestowania w rozwój dzieci powodują te rozbieżności.
} 


\section{Dzietność a gospodarka}

Dla podjętych w artykule rozważań ważne jest zwrócenie uwagi na zasadnicze dla myślenia o funkcjonowaniu społeczeństwa i jego podsystemu gospodarczego założenia dotyczące dzietności i jej znaczenia dla gospodarki. Jest to o tyle istotne, że funkcjonują uproszczone albo nieaktualne poglądy na tę kwestię. Dlatego też należy ustalić, jakie zależności mogą występować między funkcjonowaniem gospodarki a przyrostem naturalnym.

Przyglądając się dyskusji na temat wpływu procesów demograficznych - w tym dzietności - na funkcjonowanie gospodarki, da się wyróżnić trzy podejścia, których nazwy przywołamy za zespołem autorów David E. Bloom, David Canning i Jaypee Sevil$1 \mathrm{a}^{13}$. Pierwsze z nich to tzw. teoria ,pesymistyczna”, według której przyrost naturalny ma negatywny wpływ na wzrost gospodarczy, co w konsekwencji prowadzi do przekonania, że gospodarka może się rozwijać tylko wtedy, gdy liczebność populacji będzie ograniczana. Druga teoria, określana mianem „optymistycznej”, zakłada w przeciwieństwie do poprzedniej, że kiedy wzrasta liczba ludności, gospodarka lepiej prosperuje i się rozwija. Z kolei zwolennicy trzeciego podejścia, nazywanego „,neutralistycznym”, nie dostrzegają istotnego związku między dzietnością a wzrostem gospodarczym, a uwagę w większym stopniu kierują na przykład na mechanizm rynkowy jako czynnik stymulujący rozwój ${ }^{14}$.

Przechodząc do kwestii relacji między dzietnością a gospodarką, należy rozpocząć od sprawy zasadniczej, którą jest - wydawać by się mogło oczywista - reguła dotycząca trwania i ciągłości ładu społeczno-gospodarczego. Chodzi o prawidłowość, którą w demografii określa się jako, ,prostą zastępowalność pokoleń”, występującą wtedy, gdy dzietność utrzymuje się na takim poziomie, że stan liczebny populacji zostaje utrzymany lub rośnie ${ }^{15}$. Gdy jednak liczba narodzin nie przekracza progu zastępowalności pokoleń, wówczas z powodu przewagi liczby zgonów społeczeństwo ulega depopulacji.

W interesującym nas kontekście warto zauważyć, że świadomość tej zależności wydaje się niska. Dlatego należy wyraźnie podkreślić, że aby móc w ogóle podejmować wątek rozwoju społeczno-gospodarczego, musi istnieć jego podmiot, którym jest społeczeństwo, trwające i rozwijające się w długiej perspektywie o tyle, o ile utrzymuje ono dzietność na poziomie równym lub wyższym niż próg zastępowalności pokoleń (który dla współczesnych społeczeństw, w jakich występuje stosunkowo niska śmiertelność niemowląt, wynosi 2,14$)^{16}$. Dla podkreślenia, jak ważne jest zachowanie ciągłości oraz określonego poziomu odtwarzania populacji, warto przywołać argument natury ekonomicznej. Chodzi mianowicie o to, że dla zapewnienia przyszłego dobrobytu nie wystarczy „odłożyć” kapitał finansowy czy materialny „na później”. Jak tłumaczy to Stanisław Fel,

\footnotetext{
${ }^{13}$ D.E. Bloom, D. Canning, J. Sevilla, The Demographic Dividend. A New Perspective on the Economic Consequences of Population Change, Rand, Santa Monica 2003.

${ }^{14}$ Cf. Ibidem, s. 2-17.

${ }^{15}$ Cf. J.Z. Holzer, Demografia, Polskie Wydawnictwo Ekonomiczne, Warszawa 1999, s. 329.

${ }^{16}$ P. Szukalski, Czy w Polsce nastąpi powrót do prostej zastępowalności pokoleń?, "Acta Universitatis Lodziensis, Folia Oeconomica" 2009, nr 231, http://hdl.handle.net/11089/4160.
} 
z punktu widzenia gospodarczego, a zwłaszcza dóbr konsumpcyjnych, niemożliwe jest zabezpieczenie przyszłości w sensie oszczędzania poprzez magazynowanie środków. Może się to dokonać poprzez zapewnienie na przyszłość czynników produkcji. Kapitat w znaczeniu narzędzi produkcji powstaje dzięki inwestycjom, natomiast czynnik ludzki, praca, może zostać zabezpieczony przez wychowanie następców ${ }^{17}$.

Większość dyskusji na temat zależności między dzietnością a funkcjonowaniem gospodarki wydaje się pomijać powyższy - naszym zdaniem niezmiernie istotny - związek, z którego wynika, że dzietność jest warunkiem bazowym dla rozważań o gospodarce. Prowadzi to pośrednio do wniosku, że rodzina jest istotnym podmiotem wpływającym na gospodarkę, skoro to w niej dokonują się przywoływane powyżej procesy demograficzne.

Jeśli chodzi o pytanie postawione na początku tej części, to oczywiście warto pójść dalej i ukazać, w jaki sposób dotąd myślano na ten temat, o co się spierano i jakie stanowiska są obecne w dyskusji.

W temacie związku między dzietnością a gospodarką postacią najczęściej pojawiającą się jest Thomas Malthus, będący autorem dawno już sfalsyfikowanej hipotezy ${ }^{18}$, według której niczym nieograniczany przyrost naturalny musi doprowadzić do niewydolności systemu gospodarczego, skutkując m.in. klęską głodu. Istotny wkład do wykazania jej błędności wnieśli tacy badacze, jak Simon Kuznets, Julian L. Simon, Ester Boserup, a także, co ciekawe, Gary S. Becker, który najczęściej nie bywa kojarzony z takim podejściem. Jednak maltuzjański sposób myślenia wciąż jest obecny i znajduje zwolenników, pomimo że jego fałszywość została wykazana zarówno w wymiarze teoretycznym, jak i empirycznym. Ważnym głosem odnoszącym się do tego jest wypowiedź Gary’ego Beckera, który stwierdza:

\begin{abstract}
Obecnie jest dużo literatury, można rzec neomaltuzjańskiej, poświęconej szkodliwym efektom szybkiego wzrostu populacji. I wielu ludzi przyjęło z zadowoleniem gwaltowne spadki urodzeń, spadki wzrostu populacji z powodu niepłodności oraz innych przyczyn. Neomaltuzjaniści, mówiąc najskromniej, ogromnie wyolbrzymili negatywne skutki wzrostu populacji i podejrzewam, że realne efekty sq odwrotne: $w$ nowoczesnych krajach szybszy wzrost populacji w istocie byt korzystny dla wzrostu gospodarczego, a nie szkodliwy. (...) główne idee można wyrazić prosto: wzrost populacji wywotuje pozytywne efekty i wykazat wzrastajace korzyści, jak w przypadku dobroczynnych bodźców dla innowacyjności w medycynie na potrzeby większych populacji. Niestety, na te pozytywne skutki nie została zwrócona dostateczna uwaga świata akademickiego i brak ten powinien być uzupetniony ${ }^{19}$.
\end{abstract}

\footnotetext{
${ }^{17} \mathrm{~S}$. Fel, Oswalda von Nell-Breuninga koncepcja ładu społeczno-gospodarczego, Wydawnictwo KUL, Lublin 2007, s. 101.

${ }^{18}$ Cf. J.L. Simon, Więcej ludzi to większy dobrobyt, czystsze środowisko, dostatek zasobów naturalnych [w:] Ludność. Największe bogactwo świata, red. B.S. Mitra, tłum. K. Pajer, PAFERE i Wydawnictwo Prohibita, Warszawa 2010, s. 37; D. Lal, Ludność i dlugoterminowy wzrost ekonomiczny w Indiach [w:] Ludność..., s. 67. ${ }^{19}$ Cf. G.S. Becker, The Role of the Family in Modern Economic Life [w:] The Family in the New Millenium: World Voices Supporting the 'Natural' Clan, tom 1, red. A.S. Loveless, T.B. Holman, Praeger Press, Westport 2007, s. 4-5.
} 
Innym badaczem, który istotnie przyczynił się do pogłębienia rozumienia związków między dzietnością a rozwojem gospodarczym, dostarczając ważnych dowodów na pozytywny wpływ przyrostu naturalnego na sferę reprodukcji materialnej, był Julian L. Simon. Spośród dorobku tego autora warto zwrócić m.in. uwagę na obszerną pracę pt. The Resourceful Earth. A Response to Global $2000^{20} \mathrm{z}$ roku 1984, współredagowaną z Hermanem Kahnem. W książce tej znalazły się wnikliwe opracowania, w których autorzy wykazują, że wzrost liczby ludności nie stanowi zagrożenia dla dostępności i efektywności rozmaitych zasobów naturalnych, potrzebnych człowiekowi do gospodarowania i zapewnienia egzystencji. W innym miejscu Simon zwraca uwagę na to, że właśnie w latach 80 . XX wieku u wielu badaczy zajmujących się wpływem demografii na gospodarkę nastąpiła wyraźna zmiana myślenia o tych kwestiach. Należy jednakże zaznaczyć, że fakt ten nie zajął jak dotąd należnego mu miejsca w powszechnej świadomości oraz nie wydaje się respektowany przez część organizacji, które w imię ochrony środowiska postulują ograniczanie rozwoju liczebnego ludzkości, oraz podmioty z różnych powodów wspierające oraz realizujące kontrolę urodzeń ${ }^{11}$.

Istotne argumenty do opisywanej tu dyskusji wniósł Simon Kuznets, który, podobnie jak Julian L. Simon, podkreślał chociażby to, że większe zbiorowości ludzkie są w stanie w większym stopniu korzystać z ekonomii skali, oraz fakt, że im większa jest populacja, tym większy może być potencjał innowacyjności i kreatywności ${ }^{22}$. Niezmiernie ważny wkład wniosła także Ester Boserup, która wykazała m.in., że w wyniku rozwoju liczebnego populacji wzrasta presja na dostępne zasoby, co wymusza dążenie do jak najefektywniejszej ich alokacji ${ }^{23}$. Jeśli chodzi zaś o badania z ostatnich lat, na uwagę zasługuje Robert W. Fogel, który jest autorem teorii ewolucji techno-fizjologicznej. Badacz ten, chcąc pokazać skalę rozwoju, jakiego dokonała ludzkość w ostatnich stuleciach, świadomie rezygnuje z typowo ekonomicznych miar postępu, takich jak produkt krajowy brutto czy płace realne. Stosuje on w zamian wskaźniki biomedyczne, takie jak przeciętna długość życia, częstotliwość występowania chorób przewlekłych, średni wzrost, waga ciała oraz BMI (body mass index). W rezultacie z jego analiz wyłania się obraz tego, jak na tle historii ludzkości widać, że rozwój naukowo-techniczny uległ wyraźnemu przyspieszeniu i intensyfikacji w ostatnich dwu stuleciach, w których nastąpił także bezprecedensowy przyrost liczebny ludności świata ${ }^{24}$. Oznacza to, że możliwości odnośnie poziomu życia na ziemi oraz liczebność populacji nigdy wcześniej nie były większe. W przypadku Polski dowodzą tego choćby wzrastająca średnia przewidywana długość życia czy zmniejszająca się śmiertelność noworodków. Obywatele najbardziej rozwiniętych gospodarczo krajów świata nie tylko żyją coraz dłużej, ale i są coraz zdrowsi ${ }^{25}$. Gorzej sytuacja wygląda w krajach biedniejszych, jednak i w nich wartości wspomnianych wskaźników ulegają poprawie.

${ }^{20}$ The Resourceful Earth. A Response to Global 2000, red. J.L.Simon, H. Kahn, Basil Blackwell, Oxford 1984.

${ }^{21}$ Cf. J.L. Simon, op. cit., s. 28-29.

${ }^{22}$ Cf. np. S. Kuznets, Population, Income and Capital, ,International Social Science Bulletin” 1954, Vol. VI, nr 2, s. 165.

${ }^{23}$ Cf. D.E. Bloom, D. Canning, J. Sevilla, op. cit., s. 16.

${ }^{24}$ Cf. J. Godłów-Legiędź, Współczesna ekonomia. Ku nowemu paradygmatowi, Wydawnictwo C.H. Beck, Warszawa 2010, s. 94-95, R.W. Fogel, Catching up with the Economy, „The American Economic Review” 1999, Vol. 89, nr 1, s. 1-21.

${ }^{25}$ Atlas demograficzny Polski, red. D. Rogalińska, D. Szałtys, Główny Urząd Statystyczny, Departament Badań Demograficznych i Rynku Pracy, Departament Badań Regionalnych i Środowiska, Urząd Statystyczny 
Gdyby jeszcze spróbować przywołać konkretne konsekwencje malejącej dzietności, to na pierwszy plan wysuwa się zapewne postępujące starzenie się społeczeństwa. Od strony ekonomicznej w przypadku systemów emerytalnych opartych na solidarności międzypokoleniowej oznacza to, że zaburzenie proporcji między liczbą osób w wieku poprodukcyjnym a osób w wieku produkcyjnym prowadzić będzie do niewydolności finansowej i braku środków na przyszłe świadczenia. Ponadto społeczeństwo, w którym zwiększa się liczba osób starszych, staje się mniej innowacyjne i skłonne do podejmowania ryzyka, będącego przecież nieodłącznym elementem rozwoju naukowo-technicznego. Dodatkowo malejące na skutek depopulacji wsie, miasta i miasteczka prawdopodobnie będą zmagały się z potencjalnym deficytem budżetowym oraz niewypłacalnością, co wynikać będzie z konieczności utrzymania i odtwarzania infrastruktury, która w wielu przypadkach projektowana była na potrzeby większej populacji. Dotyczy to na przykład systemu kształcenia, opieki zdrowotnej, ale i infrastruktury, zarówno na obszarach niezurbanizowanych, jak i w miastach. Do tego można dodać malejący popyt, który z kolei będzie sygnałem do redukowania podaży, wskutek czego należy się liczyć, w dalszej perspektywie, ze wzrostem bezrobocia.

Pomimo ukazanych wcześniej dowodów na pozytywny wpływ dzietności na gospodarkę nadal w powszechnej świadomości obecne jest albo myślenie o przyroście naturalnym jako czynniku hamującym rozwój (maltuzjanizm i neomaltuzjanizm), albo jako o zmiennej niemającej związku z koniunkturą gospodarczą i dobrostanem społecznym. Wydaje się jednak, że stopniowo ulega to zmianie, o czym pośrednio może świadczyć to, że demografia z jej ustaleniami i prognozami coraz częściej staje się przedmiotem uwagi i refleksji. Podobnie więc jak zwiększająca się liczba ludności na świecie budziła strach przed laty, podobnie i depopulacja, której jesteśmy świadkami w ostatnich latach, staje się źródłem obaw.

\section{Przemiany dzietności a przeobrażenia społeczno-gospodarcze: możliwe przyczyny i próba interpretacji}

Zastanawiając się nad zmianami, jakie w ostatnich trzech dekadach zaszły w wymiarze dzietności w polskim społeczeństwie, należy zwrócić uwagę na kontekst gospodarczy, w jakim zachodziły. Chodzi przede wszystkim o proces transformacji ustrojowej, który - o czym należy pamiętać - nie jest powierzchownym, nieznacznym ,retuszem”, ale stanowi zasadnicze przewartościowanie i przestawienie całego ładu społeczno-gospodarczego na inne tory. W przypadku Polski oznaczało to przejście od systemu gospodarki centralnie planowanej, opartej na własności państwowej i kierowanej przez jedną partię, do demokracji rynkowej, w której dominować ma własność prywatna oraz pluralizm w wymiarze politycznym. Warto dodać, że docelowym modelem gospodarczym - zadekretowanym w ustawie zasadniczej - jest społeczna gospodarka rynkowa, która jest (...) oparta na wolności działalności gospodarczej, własności prywatnej oraz solidarności, dialogu $i$ wspótpracy partnerów społecznych $(. . .)^{26}$.

w Olsztynie, Warszawa 2017, Druk Zakładu Wydawnictw Statystycznych, s. 56 i nast.

${ }^{26}$ Cf. Konstytucja Rzeczypospolitej Polskiej z dnia 2 kwietnia 1997 r., art. 20 (Dz.U. z 1997 r. Nr 78, poz. 483). 
Co do samego procesu transformacji, to - odnośnie jego złożoności i trudności, z jakimi się wiąże - często porównuje się go do przebudowy statku na pełnym morzu. Chodzi więc o to, że społeczeństwa nie da się „,zatrzymać”, aby spokojnie i bez zakłóceń dokonać jego modyfikacji, dodać brakujące elementy czy naprawić bądź wymienić niesprawne instytucje. Transformacja stanowi ponadto bardzo poważne wyzwanie dla społeczeństwa, gdyż - jak zauważa Janina Filek - jest to niezwykle skomplikowany proces przechodzenia od stanu wyjściowego, który zamyka jakiś etap w rozwoju gospodarczym danego społeczeństwa, do stanu docelowego, który będzie nowym sposobem gospodarowania ${ }^{27}$. Jeśli chodzi o przypadek nas tu interesujący, to autorka ta trafnie stwierdza, że:

Polska transformacja (...) nie jest spokojna, poddana rygorom racjonalnego dziatania i dokładnie przemyślana przemiana niewydolnych mechanizmów gospodarki socjalistycznej na mechanizmy wolnorynkowe, ale gwattownym, radykalnym, czasami chaotycznym, a może nawet zbyt szybkim przeksztatceniem nie tylko gospodarki, ale także dotychczasowego sposobu życia całego społeczeństwa oraz systemu wartości, stanowiącego fundament istnienia każdej zbiorowości ${ }^{28}$.

Zwrócenie w powyższym cytacie uwagi na kulturę, którą rozumiemy jako wartości, normy i przekonania stojące u podstaw działań i decyzji podejmowanych w danej społeczności, uważamy za szczególnie istotne. Okazuje się bowiem - co potwierdza obserwacja przemian w Polsce - że choć u podstaw transformacji stały przede wszystkim kwestie polityczne i gospodarcze, to de facto głębokim przemianom uległ i nadal ulega ład społeczny i związany z nim styl życia. To, co dodatkowo komplikuje sytuację społeczeństwa podlegającego przemianom, i jednocześnie utrudnia przejście do modelu docelowego, to relatywizacja wartości, wynikająca z tego, że stary porządek został odrzucony (przynajmniej w wymiarze deklaratywnym), a zamiast niego nie wyłonił się jeszcze ten nowy, oczekiwany. Prowadzi to do stanu, który za Janiną Filek można określić mianem aksjologicznej bezdomności ${ }^{29}$.

To, naszym zdaniem, może stanowić ważny przyczynek dla wyjaśnienia i zrozumienia tego, na co w przypadku transformacji w pierwszej kolejności wskazuje obserwacja. Chodzi o radykalne pod wieloma względami przeobrażenia z jednej strony kontekstu codziennego funkcjonowania społeczeństwa, a z drugiej zmiany dotyczące postaw, preferencji i zachowań członków tejże zbiorowości. Starając się dość skrótowo wskazać przykładowe elementy tej transformacji, można wspomnieć chociażby o nowych regułach prowadzenia działalności gospodarczej oraz pojawieniu się nieobecnych wcześniej branż produkcyjnych i usługowych czy odmiennym obrazie stosunków pracy, która w coraz większym stopniu podlegać zaczęła regułom rynkowym. To z kolei przekładało się na zmniejszenie poczucia stabilizacji, zastępowanego zwiększoną dynamiką życia społecznego. W rezultacie zmiany pracy, miejsca zamieszkania, a także zawodu powodowały wzrastającą presję na przystosowanie się do nowych realiów.

\footnotetext{
${ }^{27}$ J. Filek, Wprowadzenie do etyki biznesu, Wydawnictwo Akademii Ekonomicznej w Krakowie, Kraków 2004, s. 69.

${ }^{28}$ Ibidem, s. 69 .

${ }^{29}$ Ibidem, s. 70.
} 
Transformacja pod względem gospodarczym przebiegała w warunkach zapaści poprzedniego systemu komunistycznego (określanego także jako nakazowo-rozdzielczy), który okazał się niewydolny w wymiarze reprodukcji materialnej. W jednym z raportów czytamy:

Sytuację gospodarczq w 1989 r. charakteryzowaty: glęboka nierównowaga, wysoka inflacja i regres w produkcji materialnej. Jednocześnie, w warunkach kryzysu gospodarczego i załamania sięfinansów państwa, zapoczatkowany zostat proces zmian w systemie ekonomicznym, mający na celu podporządkowanie zasad funkcjonowania gospodarki mechanizmom rynkowym ${ }^{30}$.

Należy także zauważyć, że zasadniczą przeszkodą w procesie budowania nowego systemu gospodarczego był niedobór kapitału finansowego niezbędnego dla inwestowania i wspierania rozwoju naukowo-technicznego. $Z$ tego powodu nierzadko mało konkurencyjne bądź upadające - w przeważającej mierze państwowe - polskie przedsiębiorstwa nie miały wielkich szans w rywalizacji z podmiotami zagranicznymi na coraz bardziej otwierającym się i podlegającym internacjonalizacji rynku ${ }^{31}$.

\section{Transformacja ustrojowa w Polsce i jej wpływ na przemiany życia społecznego}

Wszystkie wymieniane dotąd zmiany wpłynęły na życie społeczne, a zwłaszcza na wzory życia społecznego związane z zakładaniem rodziny i posiadaniem dzieci. Zagrożeniem dla tej sfery stała się także wzrastająca mobilność przestrzenna - zarówno o zasięgu krajowym, jak i międzynarodowym. Francis Fukuyama ${ }^{32}$ wymienia także inne czynniki wpływające na życie rodzinne, jak rozwój przedmieść i wydłużanie się czasu na dojazdy do miasta, co staje się konkurencją dla spędzania czasu w gronie rodzinnym. Nie można także nie zauważyć, że życie rodzinne wymaga inwestycji długoterminowych. Zdiagnozowane przez Fukuyamę przyczyny: dojazdy do pracy, kontaktowanie się za pośrednictwem nowych technologii, ,zmniejszanie się regulacyjnej roli norm społecznych” stają się jednak częścią samonapędzającego się procesu, którego finalnym akordem jest, jak to ujmuje inny autor, „wymieranie narodów” ${ }^{33}$. W krótkiej perspektywie zmiany te ograniczają możliwości rozwoju gospodarczego - np. zmniejszając podaż siły roboczej - podczas gdy w dłuższej perspektywie ich konsekwencje będą znacznie poważniejsze, co przyczyni się do utrwalania przemian społecznych i kulturowych. W rezultacie może okazać się, że nie-

\footnotetext{
${ }^{30}$ Polska 1989-2014..., s. 6; dodać należy, że od 1989 roku wskaźnik PKB dla Polski wzrósł z poziomu 5684 USD do 12828 USD w roku 2016.

${ }^{31}$ Cf. K. Poznański, op. cit.

${ }^{32}$ Cf. F. Fukuyama, Wielki Wstrząs. Natura ludzka a odbudowa porządku społecznego, Bertelsmann Media, Warszawa 2000.

${ }^{33}$ Cf. D.P. Spengler, It's Not the End of the World. It's Just the End of You. The Great Extinction of the Nations, RVP Publishers, New York 2011.
} 
jako „uwalniając” ludzi od konieczności stałego poświęcania czasu na życie rodzinne, sprawią, iż ewentualny powrót do większego zaangażowania w ten wymiar egzystencji w dalszej perspektywie będzie utrudniony lub w ogóle niemożliwy.

Oprócz przemian związanych z życiem rodzinnym, istotne znaczenie mają także przemiany związane z zakładaniem rodzin - zmniejszająca się liczba zawieranych małżeństw i wzrastająca liczba rozwodów (patrz Tabela 1), coraz późniejszy wiek zawierania pierwszego małżeństwa. Współcześnie mamy do czynienia z konsekwencjami wspomnianych wyżej czynników, trudno jednak wskazać najważniejszy z nich czy też ułożyć je w jakiś przyczynowo-skutkowy ciąg. I chociaż zapewne są one w jakimś stopniu z sobą powiązane, trudno te powiązania wymienić, opisać czy zinterpretować.

Tabela 1. Małżeństwa zawarte i rozwody (dane w tysiącach)

\begin{tabular}{|l|c|c|c|c|c|c|}
\cline { 2 - 7 } \multicolumn{1}{c|}{} & $\mathbf{1 9 8 9}$ & $\mathbf{1 9 9 5}$ & $\mathbf{2 0 0 0}$ & $\mathbf{2 0 0 5}$ & $\mathbf{2 0 1 0}$ & $\mathbf{2 0 1 3}$ \\
\hline małżeństwa & 255,7 & 207,1 & 211,2 & 206,9 & 228,3 & 180,4 \\
\hline rozwody & 47,2 & 38,1 & $42,8+1,3^{*}$ & $67,6+11,6^{*}$ & $61,3+2,8^{*}$ & $66,1+2,2^{*}$ \\
\hline
\end{tabular}

*liczba rozwodów + liczba separacji, wprowadzonej w Polsce od 1999 roku

Źródło: Polska 1989-2014, red. H. Dmochowska, GUS, 2014, s. 24

Dość jednoznacznie widoczne są natomiast efekty już wspomniane: malejąca liczba sformalizowanych małżeństw (przy wzroście liczby związków nieformalnych), malejąca liczba dzieci, krótszy czas trwania małżeństw (i wzrost liczby rozwodów). Zmianom tym towarzyszą inne, występujące łącznie z przemianami społecznymi związanymi wcześniej $\mathrm{z}$ modernizacją ${ }^{34}$, a następnie $\mathrm{z}$ komercjalizacją funkcji zarezerwowanych wcześniej dla rodziny w relacjach pomiędzy jej członkami - od opieki nad dziećmi, ich edukacją i wychowaniem (od żłobków, przedszkoli i szkół aż do szkół wyższych), do opieki nad chorymi i starszymi członkami rodziny, a nawet nad ich grobami. Utowarowieniu ulega także szereg innych zajęć związanych dotąd z życiem rodzinnym, a wśród nich sprzątanie czy codzienne zakupy. Źródeł tych zmian upatrywać można w, jak to ujęła jedna z autorek, skutkach rewolucji przemysłowej w domu ${ }^{35}$. Zwróciła ona uwagę na to, jak w amerykańskich gospodarstwach domowych stopniowo pojawiały się kolejne urządzenia mechaniczne, trwale zmieniające charakter życia rodzinnego. Skróceniu uległ więc czas przygotowywania posiłków, sprzątania, prasowania. Wraz z wyposażaniem gospodarstw domowych w centralne ogrzewanie, stały dostęp do wody, lodówki, a później kuchenki mikrofalowe, pracochłonne czynności, wymagające dotąd współpracy, a przy okazji integrujące członków wielopokoleniowych dużych rodzin, straciły znaczenie. Trudno stwierdzić, w jakim stopniu ich integrującą rolę przejęły wspomniane wyżej czynności, a potem kolejne przejawy rozwoju - urządzenia elektroniczne, radio, telewizja i internet, a później komunikatory i serwisy społecznościowe. Wszystkie te udogodnienia, wraz ze specjalistyczną wiedzą wymaganą do ich sprawnego używania, stanowią kolejną alternatywę dla życia rodzinnego.

\footnotetext{
${ }^{34}$ Cf. S. Baskerville, Freedom and the Family: The Family Crisis and the Future of Western Civilization, "Humanitas" 2009, Vol. XXII, nr 1 i 2, s. 168.

${ }^{35}$ R.S. Cowan, The "Industrial Revolution" in the Home: Household Technology and Social Change in the 20th Century, "Technology and Culture" 1976, Vol. 17, nr 1, s. 1-23.
} 
Tabela 2. Rodziny i liczba dzieci w rodzinach (dane w tysiącach)

\begin{tabular}{|l|c|c|c|}
\cline { 2 - 4 } \multicolumn{1}{c|}{} & $\mathbf{1 9 8 8}$ & $\mathbf{2 0 0 2}$ & $\mathbf{2 0 1 1}$ \\
\hline OGÓŁEM & 10226,2 & 10457,6 & 10972,5 \\
\hline małżeństwa bez dzieci & $2329,1^{*}$ & 2369,8 & 2696,4 \\
\hline małżeństwa z dziećmi & $6362,2 *$ & 5860,3 & 5456,8 \\
\hline partnerzy bez dzieci & - & 86,7 & 145,2 \\
\hline partnerzy z dziećmi & - & 110,7 & 171,3 \\
\hline samotne matki z dziećmi & 1395,6 & 1798,3 & 2174,3 \\
\hline samotni ojcowie z dziećmi & 178,2 & 231,8 & 328,6 \\
\hline ogółem liczba dzieci & 14649,9 & 14245,0 & 13294,6 \\
\hline $\begin{array}{l}\text { liczba dzieci do 24. roku życia pozostających na utrzymaniu } \\
\text { rodziców }\end{array}$ & 11592,8 & 10808,7 & 8868,8 \\
\hline
\end{tabular}

* w 1988 liczba rodzin łącznie ze związkami partnerskimi

Źródło: Polska 1989-2014, red. H. Dmochowska, GUS, 2014, s. 25

Analizując dane dotyczące liczby rodzin i dzieci (por. Tabela 2.) w Polsce, warto odnieść się do prognoz na najbliższe lata. Według GUS w 2050 roku współczynnik dzietności ma wynosić 1,52. Liczba ludności w Polsce spadnie z 38419 tys. w roku 2015 do 33950 tys. w 2050, przy jednoczesnym wzroście w społeczeństwie odsetka osób w wieku 65 lat i więcej z 14,7\% w 2013 roku do 32,7\% w 205036. Prawdopodobne jest więc dalsze pogłębienie obecnych zjawisk dotyczących życia rodzinnego, w którym dzieci będą nieoczywistym elementem, a rodzina z większą liczbą dzieci może stać się rzadkością. Już teraz 20\% małżeństw w Polsce nie ma dzieci, przy czym odsetek ten ma tendencję wzrostową. Wśród społecznych skutków tego procesu warto wspomnieć o upowszechnianiu się modelu rodziny z jednym dzieckiem. Warto także wspomnieć, że w rodzinach z mniejszą liczbą dzieci małżonkowie są bardziej skłonni zaakceptować rozwód jako reakcję na problemy w małżeństwie - ideę rozwodu bez żadnych przeszkód popiera 33\% małżonków mających jedno dziecko, wobec 4\% poparcia w rodzinach mających pięcioro dzieci i więcej37. Innym czynnikiem zwiększającym ryzyko rozwodu w małżeństwie lub rozstania w związku nieformalnym jest doświadczenie migracyjne jednego lub obojga rodziców (na początku 2017 roku deklaruje je już 20\% aktywnych zawodowo Polaków ${ }^{38}$ ). Jednym z efektów może być, częściej chyba podnoszone w mediach niż opracowaniach naukowych, ,eurosieroctwo" - czasowe lub stałe zamieszkiwanie dzieci bez co najmniej jednego z rodziców, który w tym czasie pracuje w innym kraju - zazwyczaj na Zachodzie - we wspomnianym raporcie $11 \%$ respondentów wskazywało, że za granicą pracuje matka, ojciec, a 17\%, że brat, siostra. Warto wspomnieć także o jeszcze jednym czynniku zmiany, jaka zachodzi w polskim społeczeństwie - jest nim zmniejszająca się rola religii jako regulatora życia społecznego, a rodzinnego w szczególności (zwłaszcza w środowi-

${ }^{36}$ Cf. Prognoza ludności na lata 2014-2050, red. M. Waligórska, Z. Kostrzewa, M. Potyra, L. Rutkowska, Główny Urząd Statystyczny, Warszawa 2014, www.stat.gov (data dostępu: maj 2017).

${ }^{37}$ Cf. R. Boguszewski, Polacy o rozwodach, komunikat z badań Centrum Badania Opinii Społecznej 2013, http://cbos.pl/SPISKOM.POL/2013/K_036_13.PDF (data dostępu: maj 2017).

${ }^{38}$ Cf. A. Cybulska, Praca za granica, komunikat z badań Centrum Badania Opinii Społecznej 2016, http:// cbos.pl/SPISKOM.POL/2016/K_175_16.PDF (data dostępu: maj 2017). 
sku lokalnym - parafia). W tym kontekście można wspomnieć o rozluźnianiu reguł dotyczących życia seksualnego (w tym przedmałżeńskich i pozamałżeńskich relacji seksualnych), subiektywizacji nauczania Kościoła katolickiego. Na popularności zyskują więc poglądy związane z uznaniowością religijnych wskazań dotyczących takich kwestii, jak niezamieszkiwanie młodych ludzi przed zawarciem ślubu czy też zakaz pozamałżeńskich stosunków seksualnych. Reguły te zapewne nie stanowią wyczerpującej ilustracji przedstawionych wyżej procesów, nie powinny być jednak z tego powodu bagatelizowane.

\section{Transformacja jako zmiana kulturowa i jej wpływ na dzietność}

W tym, co staraliśmy się do tej pory przedstawić, dość wyraźnie przejawiały się aspekty zmiany w obrębie wartości, norm i przekonań, a więc tego, co rozumiemy pod hasłem „kultura". Zdajemy sobie sprawę zarazem, że dogłębne przeanalizowanie tej zmiany kulturowej - bo w taki sposób można mówić o transformacji - wymaga z pewnością szerszego opracowania. Dlatego tu spróbujemy wymienić i zasygnalizować jedynie jej główne aspekty.

Malejącą dzietność interesująco można powiązać z procesem, który Ulrich Beck określa mianem demograficznego oswobodzenia, oznaczającego, że oto w XX wieku macierzyństwo - rozumiane jako zrodzenie i wychowanie potomstwa - zdaniem tego autora przestało być głównym powołaniem kobiety. Gdy obowiązki związane z opieką nad dziećmi kończą się około czterdziestego piątego roku życia, to (w znacznej mierze dzięki wydłużaniu się trwania życia) kobiecie pozostają kolejne dekady, które trzeba jakoś zagospodarować3 ${ }^{39}$. Oznacza to, że wraz z tzw. demograficznym oswobodzeniem bycie żoną i matką schodzi niekiedy na dalszy plan w hierarchii celów i wartości współczesnego społeczeństwa. Wydaje się ponadto, że gdy dokonuje się to w kontekście państwa opiekuńczego, które m.in. „gwarantuje” troskę o obywatela na starość, ze świadomości może znikać przekonanie, iż tylko dzięki pojawianiu się kolejnych pokoleń systemy emerytalne oparte na solidarności międzypokoleniowej mają szanse funkcjonować ${ }^{40}$.

Ukazując zmiany kulturowe, niewątpliwie należy zwrócić uwagę na zjawisko pluralizacji systemów wartości, które z jednej strony związane jest z problemem wspomnianej już bezdomności aksjologicznej charakteryzującej okres transformacji, a z drugiej jest istotną cechą współczesnych społeczeństw Zachodu, które w wielu aspektach stanowiły i nadal stanowią ważny punkt odniesienia i wzorzec kulturowy dla dokonujących się w Polsce przemian. W tym kontekście zasadne okazuje się postawienie pytania o to, czy ład społeczno-kulturowy, w którym równolegle uznawane i respektowane są nierzadko przeciwstawne sobie normy, wartości i przekonania, może efektywnie funkcjonować i się rozwijać ${ }^{41}$. Wydaje się, że wskutek

\footnotetext{
${ }^{39}$ Cf. U. Beck, Spoleczeństwo ryzyka. W drodze do innej nowoczesności, tłum. S. Cieśla, Wydawnictwo Naukowe Scholar, Warszawa 2002, s. 170.

${ }^{40}$ Cf. G. Esping-Andersen, Społeczne podstawy gospodarki postindustrialnej, tłum. R. Włoch, Wydawnictwo Wyższej Szkoły Pedagogicznej TWP w Warszawie, Warszawa 2010, s. 72-73.

${ }^{41}$ Wspótczesne społeczeństwo jest społeczeństwem rozdrobnionym, które utraciło swoje poczucie jedności. Opiera się ono na rosnacych funkcjonalnych różnicach występujących pomiędzy różnymi sferami spolecznymi. Jest to nowe zjawisko w historii ludzkości, kontrastujące z dawnymi społeczeństwami, które przypominaja
} 
tego wzrostu heterogeniczności kultury ${ }^{42}$ (mogącego skutkować niższą spójnością kulturową), związanego także z postępującym procesem indywidualizacji życia społecznego, budowanie relacji międzyludzkich okazuje się trudniejsze, zarówno w wymiarze ogólnospołecznym, jak i w najmniejszej skali diady, którą przez tysiąclecia najczęściej stanowiła para małżeńska. Innymi słowy, można powiedzieć, że także we współczesnym społeczeństwie polskim to, co wspólne, w coraz większym stopniu ustępuje temu, co prywatne, indywidualne ${ }^{43}$. Problem ten jest jednocześnie obecny w wymiarze socjalizacji, która jest przecież zarazem procesem wprowadzenia nowego, młodego pokolenia w kulturę danego społeczeństwa. Musi tam więc dochodzić do przeobrażeń, skoro zmienia się charakter i jakość relacji w rodzinie, która - jak stwierdzał Robert K. Merton - jest (...) najważniejszym pasem transmisyjnym, który stuży przekazywaniu wzorców kulturowych następnemu pokoleniu ${ }^{44}$.

W wymiarze tu analizowanym warto przede wszystkim zwrócić uwagę na to, że w coraz większym stopniu indywiduacja, a więc proces, $w$ którym jednostka staje się świadoma swej niepowtarzalnej osobowości $i^{45}$, a jej tożsamość podlega formowaniu, przebiegający najintensywniej w dzieciństwie i młodości, dokonuje się poza kontekstem relacji międzyludzkich. Oznacza to, że w coraz większym stopniu ,przewodnikami” po świecie dzieciństwa i dorastania są media i zawarte w nich treści. Ten wzrastający wpływ świata bezosobowego - przede wszystkim internetu - daje się zauważyć na podstawie badań uczniów szkół średnich zawartych w raporcie Młodzież 2016, z którego wynika, że

chłopcy przebywaja online przeciętnie nieco dlużej niż dziewczęta: średni czas korzystania przez nich z internetu wynosi cztery godziny i dziesięć minut dziennie, a w przypadku dziewcząt jest on mniej więcej o dwadzieścia minut krótszy ${ }^{46}$.

Z rosnącym wpływem internetu na socjalizację wiąże się m.in. problem korzystania z treści pornograficznych, które nierzadko ma początek przed dwunastym rokiem życia. Jak pisze Szymon Grzelak,

66\% chłopców i 54\% dziewczą deklaruje, że swój pierwszy kontakt z pornografia miato $w$ wieku poniżej 12 lat. 25\% chłopców (i tylko 2\% dziewczą) korzystało z pornografii więcej niż 10 razy w okresie ostatnich 30 dni. 14\% wszystkich chłopców korzystato z pornografii więcej niż 30 razy w tym okresie, czyli więcej niż raz dziennie..$^{47}$

\footnotetext{
niezróżnicowana, integralna całość., cyt. za: P. Pratley, Etyka w biznesie, tłum. M. Albigowski, Wydawnictwo Gebethner i S-ka, Warszawa 1998, s. 37.

${ }^{42}$ Cf. I. Kopytoff, Kulturowa biografia rzeczy-utowarowienie jako proces [w:] Badanie kultury. Elementy teorii antropologicznej, red. M. Kempny, E. Nowicka, Wydawnictwo Naukowe PWN, Warszawa 2005, s. 272. ${ }^{43}$ Niewątpliwie interesujące jest przy tym pytanie o to, w jakim stopniu zjawisko to wpływa z jednej strony na spadek liczby zawieranych małżeństw, a z drugiej na rosnący odsetek tych kończących się rozwodem, o czym wspominamy w tekście.

${ }^{44}$ R.K. Merton, Teoria socjologiczna i struktura społeczna, tłum. E. Morawska, J. Wertenstein-Żuławski, PWN, Warszawa 1982, s. 221.

${ }^{45}$ Słownik Języka Polskiego, http://sjp.pwn.pl/sjp/indywiduacja; 2561472 (data dostępu: maj 2017).

${ }^{46}$ Młodziez 2016, Raport CBOS i Krajowe Biuro ds. Przeciwdziałania Narkomanii, Warszawa 2016, s. 179.

${ }^{47}$ Diagnoza problemów i pozytywnego potencjału młodzieży (projekt badawczy), Instytut Profilaktyki Zintegrowanej (wrzesień 2010 - grudzień 2012), s. 2, http://www.program.archipelagskarbow.eu/_media/aktualnosci:warszawa:wyniki_badan_ipzin_sejm_2013.04.19.pdf (data dostępu: marzec 2018).
} 
Rosnący i stosunkowo łatwiejszy niż kiedyś dostęp do pornografii jest jednym z elementów procesu określanego mianem seksualizacji, który w sposób istotny oddziałuje na sferę dorastania, kształtowania tożsamości, nawiązywania relacji międzyludzkich, zawierania małżeństw oraz zakładania rodziny. Wprowadzony tu termin rozumiany jest - według raportu Amerykańskiego Towarzystwa Psychologicznego - jako

zjawisko dotyczące wspótczesnej kultury masowej i reklamy, a w ślad za nimi również innych obszarów życia społecznego, które polega na:

- sprowadzaniu wartości osoby do „seksownego” wygladu lub zachowania;

- uprzedmiotowieniu seksualnym (człowiek, a zwłaszcza kobieta, widziany jest jako obiekt użycia seksualnego innych, a nie w petni człowieczeństwa);

- narzucaniu treści i obrazów seksualnych nieadekwatnie do wieku i sytuacji.

Wedlug autorów definicji wystarczy, by jeden z powyższych elementów był zawarty w przekazie, a już możemy mówić o seksualizacji ${ }^{48}$.

Seksualizacja jest także ważnym przejawem tego, że seksualność coraz częściej oddzielana jest od relacji małżeńskich lub w ogóle wyjmowana z kontekstu relacji międzyludzkich, co prowadzi do tego, że w coraz większym stopniu potrzeby z nią związane zaspokajane są bez podejmowania długofalowych zobowiązań i wyrzeczeń. Nierzadko w tym względzie mamy do czynienia ze zjawiskiem komercjalizacji tej sfery i można dziś mówić o funkcjonowaniu kompleksowej branży, która koncentruje się na pozamałżeńskiej realizacji różnych pragnień seksualnych. Warto zwrócić uwagę właśnie na finansowy aspekt tego zjawiska, które częściej ukazywane jest w kategoriach zmiany obyczajowej i postępu społecznego. Na problem ten wskazał Jean Baudrillard, który pisał:

Pierwsze targi pornograficzne „, Sex 69” w Kopenhadze były to właśnie targi, a nie jakiś festiwal, jak zapowiadała prasa, innymi stowy, chodziło o ściśle komercyjna prezentację produktów, mająca na celu umożliwienie producentom materiatów pornograficznych zdobycia kolejnych rynków zbytu... ${ }^{49}$.

Skoro więc współcześnie pojawiają się alternatywne możliwości rozładowania popędu seksualnego, który w toku rozwoju naszej cywilizacji przez wieki ukierunkowany był na założenie rodziny opartej na monogamicznym małżeństwie kobiety i mężczyzny, to swoista konkurencja w tym zakresie musi wpływać na statystyki zawierania i rozpadu małżeństw oraz dzietności.

Innym istotnym elementem kulturowym o podłożu gospodarczym, który oddziałuje, naszym zdaniem, na dzietność, jest rozwój mentalności konsumpcjonistycznej. Co istotne, choć dotyczy ona przede wszystkim zachowań podejmowanych na rynku, to okazuje się przekraczać jego granice. W jakimś sensie można wręcz mówić o „eksplozji” konsumpcji, która nastąpiła wraz z usunięciem ograniczeń prawno-administracyjnych, jakie

\footnotetext{
${ }^{48}$ Vademecum skutecznej profilaktyki problemów młodzieży, red. S. Grzelak, Ośrodek Rozwoju Edukacji, Warszawa 2015, s. 88. Cf. Raport Amerykańskiego Towarzystwa Psychologicznego (American Psychological Association) na temat seksualizacji dziewcząt, 2013, https://www.twojasprawa.org.pl/dokumenty/RaportAPA-polski.pdf (data dostępu: marzec 2018).

${ }^{49}$ J. Baudrillard, Społeczeństwo konsumpcyjne, tłum. S. Królak, Wydawnictwo Sic!, Warszawa 2006, s. 193.
} 
wcześniej nałożone były na system gospodarczy. Oznaczało to, że popyt - z jednej strony hamowany przez lata poprzez tzw. gospodarkę niedoboru i politykę antykapitalistyczną, a z drugiej podtrzymywany i podsycany przez mający marginalny wymiar oficjalny handel za waluty dobrami z tzw. Zachodu, a także ich obrót w obszarze określanym jako czarny rynek - przynajmniej w wymiarze potencjalnym uzyskał nieporównywalnie większe możliwości zaspokojenia.

W ten sposób upowszechniać zaczął się konsumpcyjny styl życia, który nie jest tylko trendem dotyczącym rynku, ale przenika całą kulturę, by wymienić w tym miejscu choćby filozofizujące analizy życia społecznego autorstwa Zygmunta Baumana ${ }^{50}$. Jak z kolei zauważa William T. Cavanaugh:

\section{(...) w sercu konsumpcjonizmu tkwi nie tyle kupowanie samo w sobie, co chodzenie na za- kupy. Duch konsumpcjonizmu jest niespokojny, charakteryzuje go oderwanie od rzeczy, gdyż pragnienie musi być stale podtrzymywane. (...) Kultura konsumencka jest jednym z najbardziej wplywowych systemów formacyjnych wspótczesnego świata, zapewne bar- dziej wpływowym niż chrześcijaństwo. (...) Tak wplywowy system formacyjny nie jest neutralny moralnie: uczy nas określonego postrzegania świata ${ }^{51}$.}

Innym aspektem tego zjawiska, związanym ponadto z tym, co można określić mianem technicyzacji wymiany handlowej, jest coraz rzadsze nawiązywanie relacji międzyludzkich w procesie konsumpcji. Oznacza to, że nabywanie produktów i usług, które przez wieki wiązało się z koniecznością interakcji z drugim człowiekiem, obecnie coraz częściej zostaje zredukowane do krótkiego epizodu wzięcia produktu z półki sklepowej lub zamówienia go za pośrednictwem komputera czy smartfona ${ }^{52}$.

Można oczywiście o wiele szerzej analizować i opisywać przemiany kulturowe, które dokonują się współcześnie w Polsce, i w sposób istotny oddziałując na kształt i jakość relacji rodzinnych, wpływają na dzietność. Ponieważ wymagałoby to jednak obszerniejszego opracowania, mamy nadzieję, że poczynione tu nakreślenie i przybliżenie choć kilku przeobrażeń w obrębie norm, wartości i przekonań oraz podejmowanych na ich podstawie praktyk daje podstawy do twierdzenia, że mamy do czynienia z głębokimi $\mathrm{i}$ istotnymi przeobrażeniami, które zmieniają i będą zmieniały oblicze społeczne i gospodarcze Polski.

\section{Podsumowanie}

Nasze rozważania bazowały na założeniu, że zmiany dzietności w Polsce będą miały bardzo istotne konsekwencje w wymiarze społecznym, włączając w to gospodarkę. Stanowiły więc one próbę rozwinięcia ścieżki badań, która wydaje się wciąż dość rzadko uczęszczana, a której istotę trafnie streszcza Bożena Balcerzak-Paradowska, która pisze:

\footnotetext{
${ }^{50}$ Z. Bauman, Plynna nowoczesność, Wydawnictwo Literackie, Warszawa 2009.

${ }^{51}$ W.T. Cavanaugh, Pożarci. Gospodarka a powołanie chrześcijańskie, Fronda, Warszawa 2010, s. 84.

52 Ibidem, s. 81.
} 
Zachodzace w Polsce procesy demograficzne zwiazane z formowaniem się rodziny i jej rozwojem ilościowym mają i będą miaty konsekwencje dla dalszego rozwoju ludnościowego, ale również - społeczno-ekonomicznego kraju ${ }^{53}$.

Wiele wskazuje na to, że podjęty przez nas temat wzajemnych związków przemian gospodarczych i ich społecznych konsekwencji ze wskaźnikami dzietności będzie zyskiwał na znaczeniu. Im szybciej maleć będzie liczba dzieci, a w konsekwencji liczba ludności, tym bardziej będziemy uświadamiać sobie długofalowe i wieloaspektowe znaczenie tego zjawiska. Uruchamiane w różnych krajach - także w Polsce - programy mające wspierać rodziców i stymulować dzietność są dowodem na coraz poważniejsze traktowanie tego tematu w dyskursie publicznym i stopniowe uświadamianie sobie jego możliwych konsekwencji (oraz ich nieuchronności).

Wymieniane przez nas różne obszary, w których lokować można przyczyny i skutki zmniejszającej się dzietności, wskazują na wagę tego zjawiska oraz różne, pozornie tylko odległe możliwe obszary wystąpienia rozmaitych konsekwencji. Wraz ze zmniejszaniem się przeciętnej wielkości rodziny dalszemu upowszechnianiu ulegać będzie postawa rodzicielska cechująca się nastawieniem na posiadanie „dziecka” ${ }^{24}$. W ten sposób dzieci traktowane będą w większym stopniu jako swoista inwestycja, której celem jest ekonomiczny i społeczny sukces potomków, a pośrednio samych rodziców. Takie podejście obserwujemy od początku formalnej edukacji, a wspomniane wcześniej pozalekcyjne zajęcia dodatkowe okazują się tym bardziej dostępne - głównie w sensie finansowym - im mniejsza jest liczba dzieci w rodzinie.

Jeśli chodzi o rozważania tu podejmowane, to w oparciu o wiedzę, jaką dysponujemy, przyjmujemy za najbardziej wiarygodne stanowisko, które zauważa pozytywny wpływ przyrostu naturalnego na sferę gospodarowania. Nasze przekonanie można wyrazić w postaci założenia, według którego należy przyjąć, że nie ma (rozwijającej się) gospodarki bez (reprodukującego się) społeczeństwa, które traci swą ciągłość i ryzykuje swoim trwaniem bez określonego, wystarczającego przyrostu naturalnego. Prawdopodobnie największym wyzwaniem pozostaje zmiana świadomości społecznej związanej z miejscem i rolą dzieci w rodzinie. Nie uważamy, że zachodzące na tym obszarze zmiany są egzemplifikacją upadku rodziny, chociaż uzasadnione jest używanie przez wielu autorów określenia „kryzys”. Sądzimy, że za „kryzysową” diagnozą przemawia wiele wskaźników, które dotyczą tak postrzegania życia rodzinnego, jak i konsekwencji jego przemian dla życia społecznego w ogóle.

\footnotetext{
${ }^{53}$ B. Balcerzak-Paradowska, Założenia umowy społecznej w zakresie polityki rodzinnej [w:] Umowa społeczna. Gospodarka-Praca-Rodzina-Dialog, red. J. Wratny, Instytut Pracy i Spraw Socjalnych, Warszawa 2006, s. 56. ${ }^{54}$ Podejście takie trafnie oddaje Gary S. Becker, który próbuje ukazać decyzje i oczekiwania rodzicielskie jako wybory ekonomiczne. Pisze on, że dzieci traktowane sa jako pewne trwałe dobra konsumpcyjne, przynoszace rodzicom dochód, przede wszystkim - dochód psychiczny. Rozrodczość jest wyznaczana przez dochód, koszty dziecka, informacje, niepewność oraz gusty. Wzrost dochodu i spadek ceny prowadzi do wzrostu popytu na dzieci, jakkolwiek należy tu odróżniać ilość i jakość ,,zapotrzebowanego” potomstwa. Jakość dzieci zależy bezpośrednio od wydatkowanych na nie sum. Każda rodzina jest zmuszona produkować swoje dzieci, nie można ich bowiem kupować ani sprzedawać na rynku. Dlatego właśnie każdy element niepewności w produkcji dzieci (jak na przykład kwestia płci dziecka) wywołuje niepewność w konsumpcji. G.S. Becker, Ekonomiczna teoria zachowań ludzkich, tłum. H. Hagemajerowa, K. Hagemajer, PWN, Warszawa 1990, s. 326.
} 
Wiele wskazuje na to, że jesteśmy świadkami największych przemian życia rodzinnego w historii - ostatnie dziesięciolecia to bezprecedensowy spadek dzietności, radykalne przedefiniowanie rodziny jako trwałego związku dwojga osób przeciwnej płci czy też zmiany w obrębie wyobrażeń o funkcjach spełnianych przez rodzinę czy moralnych powinnościach dotyczących solidarności międzypokoleniowej. Wiele wskazuje na to, że te trendy będą w najbliższych latach ulegały pogłębieniu, prowadząc do przemian, które trudno sobie dzisiaj wyobrazić.

\section{Bibliografia}

Atlas demograficzny Polski, red. D. Rogalińska, D. Szałtys, Główny Urząd Statystyczny, Departament Badań Demograficznych i Rynku Pracy, Departament Badań Regionalnych i Środowiska, Urząd Statystyczny w Olsztynie, Druk Zakładu Wydawnictw Statystycznych, Warszawa 2017.

Badora B., Wydatki rodziców na edukację dzieci w roku szkolnym 2016/2017, Raport z badań Centrum Badania Opinii Społecznej 2016, http://cbos.pl/SPISKOM.POL/2016/K_157_16.PDF.

Balcerzak-Paradowska B., Założenia umowy społecznej w zakresie polityki rodzinnej [w:] Umowa społeczna, red. J. Wratny, Instytut Pracy i Spraw Socjalnych, Warszawa 2006.

Baskerville S., Freedom and the Family: The Family Crisis and the Future of Western Civilization, "Humanitas" 2009, Vol. XXII, nr 1 i 2, s. 168-184.

Baudrillard J., Społeczeństwo konsumpcyjne, tłum. S. Królak, Wydawnictwo Sic!, Warszawa 2006.

Bauman Z., Ptynna nowoczesność, Wydawnictwo Literackie, Warszawa 2009.

Beck U., Społeczeństwo ryzyka. W drodze do innej nowoczesności, tłum. S. Cieśla, Wydawnictwo Naukowe Scholar, Warszawa 2002.

Becker G.S., Ekonomiczna teoria zachowań ludzkich, tłum. H. Hagemajerowa, K. Hagemajer, PWN, Warszawa 1990.

Becker G.S., The Role of the Family in Modern Economic Life [w:] The Family in the New Millenium: World Voices Supporting the 'Natural' Clan, tom 1, red. A.S. Loveless, T.B. Holman, Praeger Press, Westport 2007.

Bloom D.E., D. Canning, J. Sevilla, The Demographic Dividend. A New Perspective on the Economic Consequences of Population Change, Rand, Santa Monica 2003.

Boguszewski R., Polacy o rozwodach, komunikat z badań Centrum Badania Opinii Społecznej 2013, http://cbos.pl/SPISKOM.POL/2013/K_036_13.PDF.

Cavanaugh W.T., Pożarci. Gospodarka a powołanie chrześcijańskie, Fronda, Warszawa 2010.

Cowan R.S., The "Industrial Revolution" in the Home: Household Technology and Social Change in the 20th Century, "Technology and Culture" 1976, Vol. 17, nr 1, s. 1-23.

Cybulska A., Praca za granica, komunikat z badań Centrum Badania Opinii Społeczne, 2016, http://cbos.pl/SPISKOM.POL/2016/K_175_16.PDF.

Diagnoza problemów i pozytywnego potencjału młodzieży (projekt badawczy), Instytut Profilaktyki Zintegrowanej (wrzesień 2010 - grudzień 2012), http://www.program.archipelagskarbow. eu/_media/aktualnosci:warszawa:wyniki_badan_ipzin_sejm_2013.04.19.pdf.

Esping-Andersen G., Społeczne podstawy gospodarki postindustrialnej, tłum. R. Włoch, Wydawnictwo Wyższej Szkoły Pedagogicznej TWP w Warszawie, Warszawa 2010. 
Fel S., Oswalda von Nell-Breuninga koncepcja ładu społeczno-gospodarczego, Wydawnictwo KUL, Lublin 2007.

Fertility statistics, Eurostat, http://ec.europa.eu/eurostat/statistics-explained/index.php/Fertility_ statistics.

Filek J., Wprowadzenie do etyki biznesu, Wydawnictwo Akademii Ekonomicznej w Krakowie, Kraków 2004.

Fogel R.W., Catching up with the Economy, „The American Economic Review” 1999, Vol. 89, nr 1, s. $1-21$.

Fukuyama F., Wielki Wstrzas. Natura ludzka a odbudowa porządku społecznego, Bertelsmann Media, Warszawa 2000.

Godłów-Legiędź J., Współczesna ekonomia. Ku nowemu paradygmatowi, Wydawnictwo C.H. Beck, Warszawa 2010.

Holzer J.Z., Demografia, Polskie Wydawnictwo Ekonomiczne, Warszawa 1999.

Kołodko G.W., Droga do teraz, Prószyński i S-ka, Warszawa 2014.

Konstytucja Rzeczypospolitej Polskiej z dnia 2 kwietnia 1997 r. (Dz.U. z 1997 r. Nr 78, poz. 483).

Kopytoff I., Kulturowa biografia rzeczy - utowarowienie jako proces [w:] Badanie kultury. Elementy teorii antropologicznej, red. M. Kempny, E. Nowicka, Wydawnictwo Naukowe PWN, Warszawa 2005.

Kuznets S., Population, Income and Capital, „International Social Science Bulletin” 1954, Vol. VI, nr 2, s. 165-170.

Lal D., Ludność i dlugoterminowy wzrost ekonomiczny w Indiach [w:] Ludność. Największe bogactwo świata, red. B.S. Mitra, tłum. K. Pajer, PAFERE i Wydawnictwo Prohibita, Warszawa 2010.

Martin J., E. Whitehouse, The conflict between generations: Fact or fiction?, OECD Observer, oecdobserver.org:_Fact_or_fiction_html.

Merton R.K., Teoria socjologiczna i struktura społeczna, tłum. E. Morawska, J. Wertenstein-Żuławski, PWN, Warszawa 1982.

Młodzież 2016, Raport CBOS i Krajowe Biuro ds. Przeciwdziałania Narkomanii, Warszawa 2016.

Niska Dzietność w Polsce w kontekście percepcji Polaków. Diagnoza społeczna 2013, red. I.E. Kotowska, Warszawa 2014.

Polska 1989-2014, red. H. Dmochowska, Główny Urząd Statystyczny, www.stat.gov.

Poznański K., Obłęd reform. Wyprzedaż Polski, Ludowa Spółdzielnia Wydawnicza, Warszawa 2001.

Pratley P., Etyka w biznesie, tłum. M. Albigowski, Wydawnictwo Gebethner i S-ka, Warszawa 1998.

Prognoza ludności na lata 2014-2050, red. M. Waligórska, Z. Kostrzewa, M. Potyra, L. Rutkowska, Główny Urząd Statystyczny, Warszawa 2014, www.stat.gov.

Raport Amerykańskiego Towarzystwa Psychologicznego (American Psychological Association) na temat seksualizacji dziewcząt, 2013, www.twojasprawa.org.

Roguska B., Ocena programu ,Rodzina 500+” po blisko roku od jego wprowadzenia, Komunikat z badań Centrum Badania Opinii Społecznej nr 36/2017, www.cbos.pl.

Simon J.L., Więcej ludzi to większy dobrobyt, czystsze środowisko, dostatek zasobów naturalnych, [w:] Ludność. Największe bogactwo świata, red. B.S. Mitra, tłum. K. Pajer, PAFERE i Wydawnictwo Prohibita, Warszawa 2010. 
Stownik Jęzka Polskiego, http://sjp.pwn.pl/sjp/indywiduacja;2561472.

Spengler D.P., It's Not the End of the World. It's Just the End of You. The Great Extinction of the Nations, RVP Publishers, New York 2011.

Stańczak J., K. Stelmach, M. Urbanowicz, Matżeństwa oraz dzietność w Polsce, GUS 2016.

Szukalski P., Czy w Polsce nastapi powrót do prostej zastępowalności pokoleń?, „Acta Universitatis Lodziensis, Folia Oeconomica" 2009, nr 231, http://hdl.handle.net/11089/4160.

Szukalski P., Czym jest solidarność międzypokoleniowa? [w:] Jakość życia seniorów w XXI wieku z perspektywy polityki społecznej, red. D. Kałuża, P. Szukalski, Wydawnictwo Biblioteka, Łódź 2010.

The Resourceful Earth. A Response to Global 2000, red. J.L. Simon, H. Kahn, Basil Blackwell, Oxford 1984.

Tyszka Z., A. Wachowiak, Podstawowe pojęcia i zagadnienia socjologii rodziny, Wydawnictwo Akademii Rolniczej im. A. Cieszkowskiego, Poznań 1997.

Ulgi podatkowe i świadczenia rodzinne w UE, Raport PriceWaterHouseCoopers, listopad 2015.

Vademecum skutecznej profilaktyki problemów młodzieży, red. S. Grzelak, Ośrodek Rozwoju Edukacji, Warszawa 2015.

Woźniak M.G., Współczesne niedostosowania instytucjonalne z perspektywy wyzwań rozwojowych Polski, „Nierówności Społeczne a Wzrost Gospodarczy” 2017, nr 50 (2), DOI:10.15584/ nsawg.2017.2.1.

Zamagni S., Rodzina jako podmiot gospodarczy, „Społeczeństwo” 2003, nr 2 (54).

Ziółkowski M., Przemiany interesów i wartości społeczeństwa polskiego, Humaniora, Poznań 2000. 